\title{
The Study of Ethanol Extracts Composition of Organic (Kachkulnya Lake) and Organomineral (Barchin Lake) Sapropels from Novosibirsk Region
}

\author{
Victor I. Sharypov*, Natalia G. Beregovtsova, \\ Sergey V. Baryshnikov and Aleksey V. Rudkovsky \\ Institute of Chemistry and Chemical Technology SB RAS \\ 50-24 Akademgorodok, Krasnoyarsk, 660036, Russia
}

Received 26.03.2015, received in revised form 07.05.2015, accepted 26.06.2015

The extraction of sapropels of organic type (Kachkulnya Lake) and organo-mineral type (Barchin Lake) from Novosibirsk region by ethanol at a variation of process temperature was studied. It was shown that the rising of the temperature from $50{ }^{\circ} \mathrm{C}$ to $200{ }^{\circ} \mathrm{C}$ results in an increase the yields of extracts by 19,0 and 13,7 times for sapropels organic and organo-mineral-types respectively

The composition of obtained extracts was established by IR and GC-MC methods. Products from sapropel organic type contained $68,1 \%$ ethyl esters, mainly of fatty acids with carbon atoms in the molecule are from 18 to 29 numbers. It was established that relative content of ethyl esters in extract of organo-mineral type sapropel was 43,6\%, they have a significant amounts of ethyl esters of hydroxyand oxyacids. A distinctive feature of the ethanol extract from organo-mineral type sapropel is the presence of carbohydrates and compounds containing a furan ring.

Keywords: lake sapropel, extraction, ethanol, FTIR, GC-MS, products composition.

DOI: 10.17516/1998-2836-2015-8-3-401-412.

(c) Siberian Federal University. All rights reserved

* Corresponding author E-mail address: sharypov@icct.ru 


\title{
Изучение состава этанольных экстрактов \\ сапропелей Новосибирской области \\ органического (оз. Качкульня) \\ и органоминерального (оз. Барчин) типов
}

\author{
В.И. Шарыпов, Н.Г. Береговцова, \\ С.В. Барышников, А.В. Рудковский \\ Институт химии и химической технологии СО РАН \\ Россия, 660036, Красноярск, Академгородок, 50/24
}

Изучена экстракция сапропелей Новосибирской области органического (оз. Качкульня) и органоминерального (оз. Барчин) типов этанолом при варьировании температуры процесса. Повышение температуры от 50 до $200{ }^{\circ} \mathrm{C}$ приводит к увеличению выхода экстрактов в 19,0 и 13,7 раз для сапропелей органического и органоминерального типов соответственно.

Методами ИК-спектроскопии и хромато-масс-спектрометрии установлен состав полученных экстрактов. Продукты из сапропеля органического типа содержат 68,1 \% этиловых эфиров, преимущественно жирных кислот с числом атомов углерода в молекуле от 18 до 29. В экстрактах сапропелей органоминерального типа относительное содержание этиловых эфиров составляет 43,6 \%, в состав которых кроме этиловых эфиров жирных кислот входят в значительных количествах этиловые эфиры окси- и гидроксикислот. Отличительной особенностью экстрактов сапропеля органоминерального типа является наличие в нем углеводов и соединений, включающих в свой состав фурановый цчикл.

Ключевые слова: озерный сапропель, экстракиия, этанол, ИКС, хромато-масс-спектрометрия, состав продуктов.

\section{Введение}

Выявленный запас сапропелей в России составляет более 250 млрд м³ ${ }^{3}$ наибольшее количество месторождений расположено в Центральном, Западно-Сибирском и Северо-Западном регионах [1]. Сапропели - мультикомпонентные системы, включающие в свой состав органические, органоминеральные и неорганические вещества. По содержанию минеральной части их обычно разделяют на органические (зольность 6-30 мас.\%) и органоминеральные (зольность от 30 до 85 мас.\%) [1-2]. В настоящее время сапропели используются в лечебных и косметических целях, для производства органоминеральных удобрений, минерально-витаминных добавок к кормам для животных.

Установлено, что продукты, выделенные из сапропелей экстракцией органическими растворителями при комнатной температуре или в Сокслете, содержат широкий набор органических соединений, включающих липиды, углеводы, терпеновые углеводороды, парафины, фенолы, которые могут быть использованы в качестве сырья для производства востребованных 
продуктов [3, 4]. При этом выход экстрактов существенно зависит от типа сапропелей, глубины их залегания, условий формирования озер и т.д. Обычно выход таких экстрактов невысок. Так, в процессе экстракции сапропеля оз. Карасево Томской области смесью этанол-хлороформ (1:3) по объему при комнатной температуре в течение 48 ч выход экстрактов составил 1,19$3,79 \%$ в расчете на массу абсолютно сухого сапропеля [5]. Выход гексанового экстракта из органоминерального сапропеля (оз. Глубокое, Татарстан) равнялся 0,5 мас.\% от массы органического вещества сапропеля, толуольного 0,8 мас.\%, хлороформенного 0,3 мас.\%, ацетонового 0,5 мас.\%, этанольного 1,3 мас.\% [6]. Эти обстоятельства определяют необходимость повышения эффективности процессов экстракции целевых продуктов из донных отложений и подобного органоминерального сырья.

Наиболее распространенными методами достижения этой цели являются измельчение и механическая активация сырья [7], сверхкритическая экстракция $\mathrm{CO}_{2}[4,8]$, обработка ультразвуком [9]. Кроме того, в литературе имеются сведения об интенсификации процессов экстракции вибромагнитным воздействием в водной среде [3], сверхкритической экстракцией этанолом [10] и рядом других методах.

Повышенный выход липидов был получен при экстракции сырья органическими растворителями или их смесями при температурах выше температуры их кипения (в нормальных условиях) и повышенных давлениях, обеспечивающих нахождение экстрагентов в выбранных условиях в жидкой фазе. С этой целью использовали следующие экстрагенты: дихлорметан гексан [11, 12], дихлорметан-метанол (9:1) [10, 13], дихлорметан-циклогексан [14, 15], метанол $[16,17]$, этанол [18]. Авторы сделали вывод о перспективности использования этих методов для повышения эффективности выделения липидов, восков, терпеновых соединений и т.д. из данного вида сырья.

В настоящей работе проведена экстракция сапропелей Новосибирской области органического (оз. Качкульня) (C-1) и органоминерального (оз. Барчин) (C-2) типов этанолом при различной температуре и исследованы особенности состава полученных продуктов.

\section{Экспериментальная часть}

В настоящей работе использовали воздушно-сухие сапропели с размером частиц менее 0,2 мм. Предварительно были определены влажность и зольность образцов высушиванием до постоянного веса при $100{ }^{\circ} \mathrm{C}$ и озолением высушенного образца при $830{ }^{\circ} \mathrm{C}$. Содержание органической массы в высушенных при $100{ }^{\circ} \mathrm{C}$ сапропелях рассчитывали как 100 мас.\% - (зольность, мас.\% + влажность, мас.\%). Проведенные ранее исследования [9] показали, что выбранные сапропели существенно различаются по содержанию органического вещества (OB). Сапропель C-1 содержит почти в 2 раза больше $\mathrm{OB}$, чем сапропель С-2. Их элементный состав изменялся в пределах (\% на органическую массу вещества): С - 45,8 - 49,1; H - 5,7 - 6,6; N - 3,4 4,0; S - 5,2 6,4; O - 36,5 - 37,3.

Экстракцию воздушно-сухих сапропелей этанолом (95 мас.\%) проводили следующими способами.

Способ 1. 10 г воздушно-сухого сапропеля помещали в 250 -миллилитровую колбу с обратным холодильником, добавляли 100 мл этанола (96 мас.\%) и нагревали при перемешивании до $50{ }^{\circ} \mathrm{C}$, выдерживали при этой температуре в течение 24 ч. Затем смесь фильтровали, остаток 
на фильтре промывали этанолом. Из полученного раствора отгоняли примерно 90 об. \% этанола на роторном испарителе без нагревания под вакуумом (70 мм рт. ст.). Концентрированный раствор переносили частями в предварительно взвешенный тонкостенный бюкс, помещенный в вытяжной шкаф, и выдерживали до образования осадка. Остатки этанола удаляли из осадка откачиванием под вакуумом до постоянного веса (1 мм рт. ст.). По разности массы пустого бюкса и бюкса с осадком, доведенного до постоянной массы, определяли массу экстракта $\left(m_{1}\right)$ и вычисляли его выход $(\alpha)$ в расчете на массу сухого органического вещества $(\mathrm{OB})$ сапропеля по формуле

$$
\alpha=\frac{m_{1}}{m_{0}\left(1-\frac{A_{0}+W_{0}}{100}\right)} \times 100 \%,
$$

где $m_{0}$ - масса воздушно-сухого сапропеля, взятого на экстракцию; $A_{0}$ и $W_{0}$ - его зольность и влажность соответственно.

Способ 2. 10 г сапропеля помещали в Сокслет в патроне из предварительно взвешенной фильтровальной бумаги и проводили экстракцию этанолом в течение 6 ч. Перед экстракцией Сокслет утепляли асбестовым жгутом. Температуру стенки Сокслета измеряли термопарой. В процессе экстракции температура составляла $(76 \pm 1){ }^{\circ} \mathrm{C}$. После завершения процесса полученный раствор экстракта в этаноле и твердый остаток экстракции обрабатывали аналогично способу 1.

Способ 3. 12 г сапропеля помещали в автоклав, добавляли туда 45 мл этанола. Сосуд герметично закрывали, продували десятикратным количеством аргона для удаления воздуха, включали вращение автоклава и нагревали до $200^{\circ} \mathrm{C}$. За начало процесса считали момент достижения заданной температуры. Продолжительность процесса составляла 60 мин, давление в автоклаве - 4,7 МПа. После проведения эксперимента и охлаждения печи содержимое автоклава количественно выгружали вымыванием этанолом и фильтровали. Остаток на фильтре экстрагировали этанолом аналогично способу 2.

Этанольные экстракты сапропелей, полученные методами 1 и 2, исследовали методами ИК-спектроскопии. Инфракрасные спектры сапропелей снимали с использованием ИК-Фурье спектрометра «Vektor 22», Bruker. Обработка спектральной информации проведена по программе OPUS/YR (версия 2,2). Образцы для анализа готовили в виде таблеток в матрице KBr.

Вещественный состав экстрактов, выделенных методом 3, определяли с помощью хроматографа Agilent 7890A, снабженного детектором масс Agilent 7000A Triple Quad при регистрации полного ионного тока. Разделение продуктов осуществляли на капиллярной колонке HP-5MS длиной 30 м с внутренним диаметром 0,25 мм при программировании температуры в интервале 40-250 c (скорость подъема температуры 3 ॰с/мин).

\section{Результаты и обсуждения}

Полученные результаты показали, что при температурах экстракции 50 и $76{ }^{\circ} \mathrm{C}$ выход экстрагируемых продуктов невысок и практически не зависит от типа сапропеля. Повышение температуры до $200{ }^{\circ} \mathrm{C}$ приводит к резкому росту выхода экстрактов сапропеля (рис. 1). Предварительно были проведены эксперименты с этанолом без добавления сапропеля. Методами

$$
-404-
$$




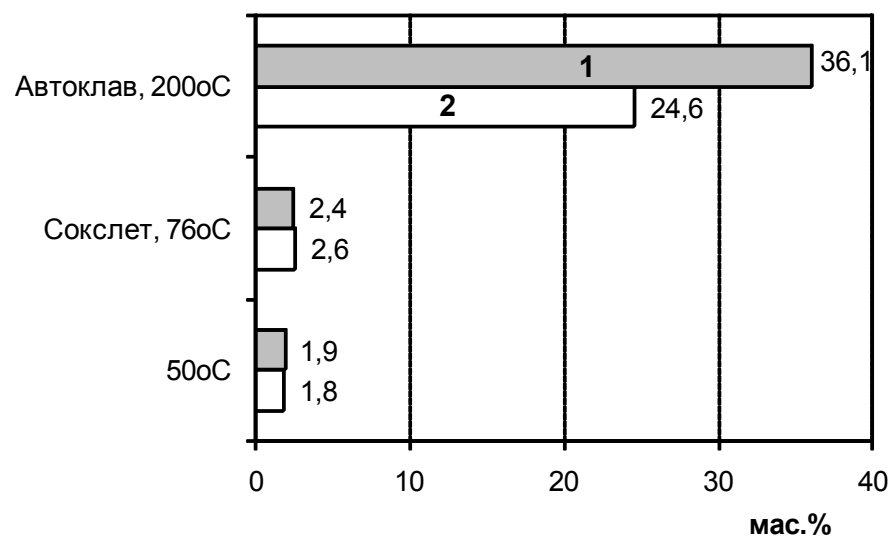

Рис. 1. Выход продуктов экстракции сапропелей этанолом в расчете на абсолютно сухое органическое вещество сапропеля: 1 - сапропель органического типа (C-1); 2 - сапропель органоминерального типа (C-2)

газовой хроматографии и хромато-масс-спектрометрии образование газообразных и конденсированных продуктов не было зафиксировано. Эти результаты показывают, что при температуре экстракции $200{ }^{\circ} \mathrm{C}$ и давлении в автоклаве 4,7 МПа превращение этанола не происходит. Согласно полученным нами ранее результатам дальнейшее повышение температуры процесса экстракции нежелательно, т.к. сопровождается снижением выхода экстрагируемых продуктов, вероятно, в результате их термического разложения [10].

В ИК-спектрах экстрактов (рис. 2, 3), полученных методом 1 и 2, присутствуют интенсивные полосы поглощения при 2919 и $2850 \mathrm{~cm}^{-1}$, а также 1467 и $1377 \mathrm{~cm}^{-1}$, соответствующие валентным и деформационным колебаниям $\mathrm{CH}_{3}$ - и $\mathrm{CH}_{2}$-алифатических групп. Наличие в спектрах полосы поглощения при $720 \mathrm{~cm}^{-1}$ указывает на то, что в структуре молекул экстрактов имеются алифатические углеводородные цепи длиной не менее 4 атомов углерода. Полосы поглощения при 1740-1700, 1315-1280, 960-875 см -1 могут быть отнесены к поглощению карбонильных и карбоксильных групп, причем их интенсивность в экстрактах из сапропеля С-1 несколько выше, чем соответствующие полосы в экстрактах из сапропеля С-2. Полосы поглощения в области 3600-3400 см-1 соответствуют валентным колебаниям ОН-карбоксильной группы. Эти данные позволяют предположить, что в состав экстрактов в значительном количестве входят карбоновые кислоты с числом атомов углерода в цепи более 4. В спектре экстракта сапропеля органоминерального типа (C-2) наблюдается слабая полоса поглощения валентных колебаний N-H в области $3200 \mathrm{~cm}^{-1}$ и группы полос C-N (сл.) при 1050 см$^{-1}$, что свидетельствует об увеличении в составе органического вещества азотсодержащих соединений.

По данным хромато-масс-спектрометрии продукты, экстрагируемые этанолом из сапропелей при $50{ }^{\circ} \mathrm{C}$, содержат летучие соединения в небольшом количестве. Последние включают в себя в случае органоминерального сапропеля некоторые азотсодержащие соединения и метил фурфурол, а для сапропеля органического типа - преимущественно фенолы. Экстракты, полученные при $200{ }^{\circ} \mathrm{C}$, характеризуются высоким относительным содержанием метиловых эфиров карбоновых кислот (рис. 4). Учитывая, что подобные соединения не были обнаружены в экстрактах, полученных при $50{ }^{\circ} \mathrm{C}$, можно полагать, что они образуются в результате реакций

$$
-405-
$$




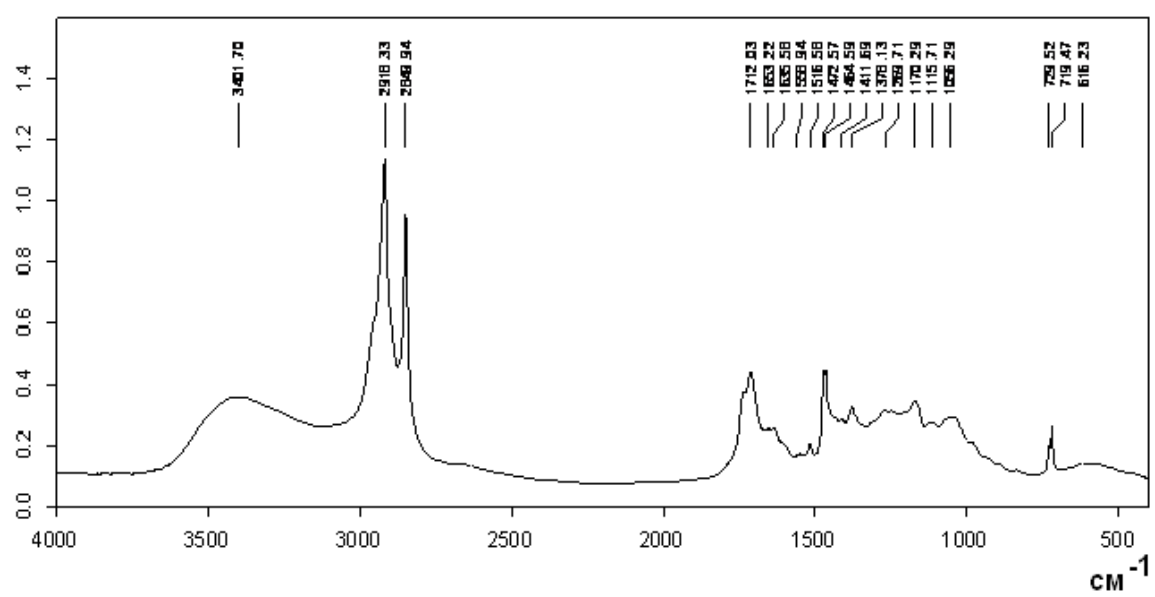

Рис. 2. ИК-спектр продукта, полученного экстракцией сапропеля органического типа (C-1) этанолом при $50{ }^{\circ} \mathrm{C}$

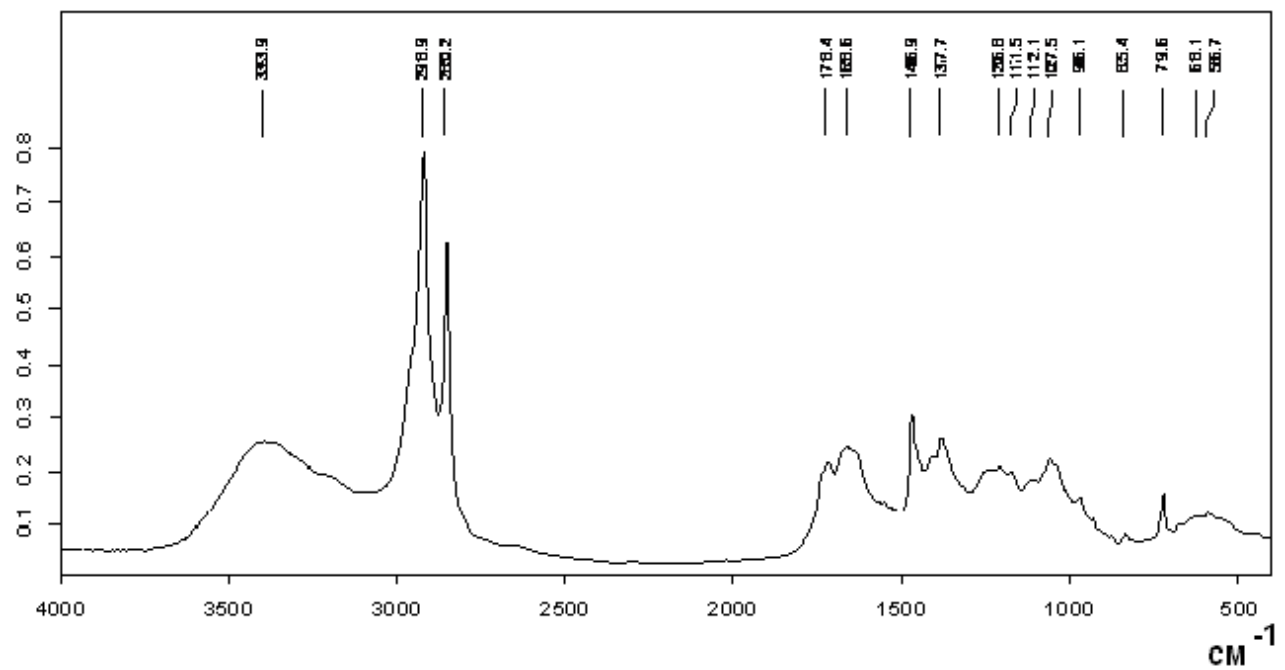

Рис. 3. ИК-спектр продукта, полученного экстракцией сапропеля органоминерального типа (C-2) этанолом при $50{ }^{\circ} \mathrm{C}$

этерификации этанолом соответствующих кислот в процессе экстракции сапропелей при повышенной температуре.

Результаты показывают, что экстракты сапропеля органического типа (C-1) характеризуются более высоким, по сравнению с продуктами из органоминерального сапропеля (C-2), относительным содержанием этиловых эфиров карбоновых кислот (рис. 1). Эфиры из сапропеля C-1 представлены в основном производными предельных жирных кислот от гексадекановой до гептакозановой с преимущественно четным количеством атомов углерода в молекуле (табл. 1). Наиболее высокое относительное содержание было определено для этилового эфира октакозановой (монтановой) кислоты (С30) - 14,5 \%, этилового эфира тетракозановой (лигно-

$$
-406-
$$




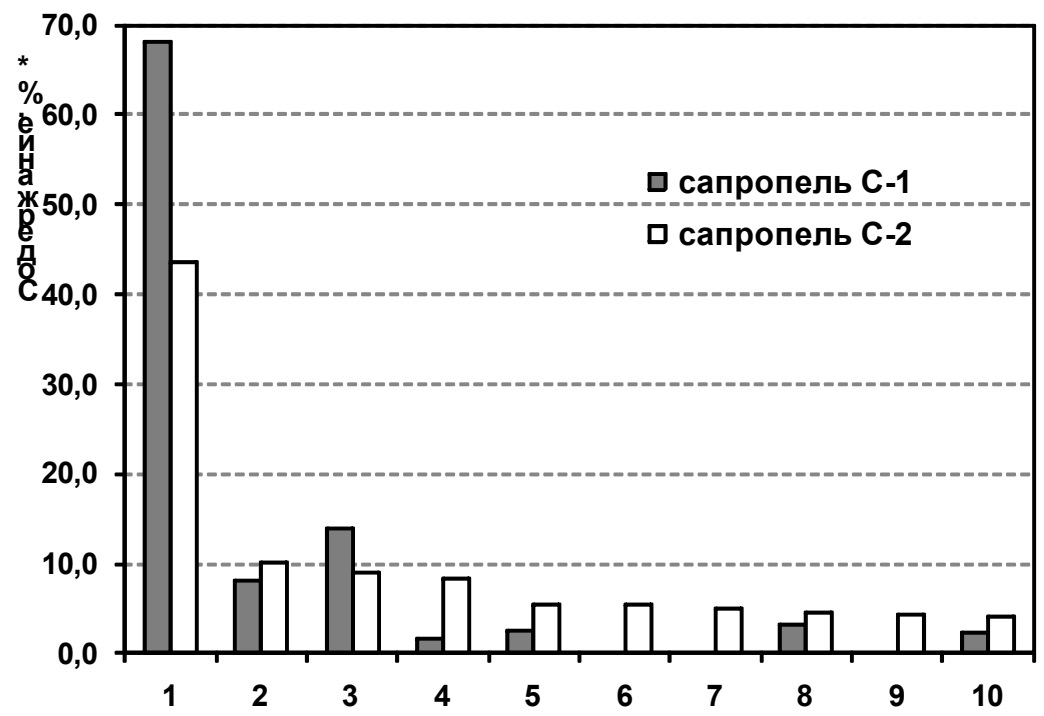

Рис. 4. Групповой состав, рассчитанный из данных табл. 1 и 2, продуктов, полученных экстракцией органического и органоминерального сапропелей этанолом при $200{ }^{\circ} \mathrm{C}: 1$ - сложные эфиры; 2 - азотсодержащие соединения; 3 - фенолы; 4 - кетоны, альдегиды; 5 - неидентифицированные; 6 - производные бензола; 7 - фураны; 8 - углеводороды; 9 - углеводы; 10 - серосодержащие соединения

цериновой) кислоты (C26) - 10,8 \%. Экстракт, выделенный из сапропеля C-2, характеризуется повышенным количеством этиловых эфиров гидрокси- и оксикислот. Среди них значительное относительное содержание установлено для: этилового эфира 2-гидроксипропановой (молочной) кислоты - 8,3 \% и этилового эфира 4-оксипентановой (левулиновой) кислоты - 2,0 \%, что, соответственно, в 13,8 и 5,0 раз больше, чем в продуктах из сапропеля С-1. Эфиры жирных кислот, образующиеся из сапропеля $\mathrm{C}-2$, представлены производными от ноненовой до октадекановой кислоты, т.е. в целом имеют меньшую молекулярную массу, чем эфиры из сапропеля С-1. Максимальное относительное содержание в этом ряду соединений обнаружено для этилового эфира гексадекановой (пальмитиновой) (С18) кислоты - 8,2%.

Фенольные соединения, входящие в состав экстрактов обоих сапропелей, в основном представлены гваяколом и его замещенными производными. Существенные различия наблюдались в составе азотсодержащих соединений. Наибольшее их содержание в составе экстрактов из сапропеля С-1 обнаружено для 5-гидроксиметил, 2-пирродилинона - 3,9 \% и 3-изобутилгексагидропирроло-(1,2-a)-пиразин-1,4-диона - 2,1 \%, в то время как продукты из сапропеля С-2 включали этиловый эфир карбаминовой кислоты (уретан) - 3,9 \% и метил 6-деокси-2-О-метилгексапиранозид - 3 \% (табл. 1, 2).

Отличительной особенностью экстрактов сапропеля С-2 является наличие в его составе следующих веществ, отсутствующих в продуктах из сапропеля С-1: углеводы, с наибольшим содержание среди которых обнаружен метил-6-деокси-2-О-метилгексапиранозид - 3 \%; и соединения, включающие в свой состав фурановый цикл, такие как 5 -метил фурфурол - 1,7 \%. Этот факт, а также отмеченное ранее повышенное содержание в сапропеле органоминерального типа (C-2), 2-гидроксипропановой (молочной) и 4-оксипентановой (левулиновой) кислот указывает на то, что заметную роль в образовании этого сапропеля играли целлюлоза и ге-

$$
-407-
$$


Таблица 1. Вещественный состав продуктов, полученных экстракцией сапропеля органического типа C-1 в этаноле при $200{ }^{\circ} \mathrm{C}$

\begin{tabular}{|c|c|c|c|c|c|}
\hline № & Соединение & $\% *$ & № & Соединение & $\% *$ \\
\hline 1 & $\begin{array}{l}\text { этиловый эфир } 2 \text { - гидрокси } \\
\text { пропановой (молочной) кислоты }\end{array}$ & 0,6 & 22 & $\begin{array}{l}\text { этил (2Е)-3-(4-гидроксифенил) } \\
\text { 2-пропеноат (этиловый эфир п } \\
\text {-кумаровой кислоты) }\end{array}$ & 1,4 \\
\hline 2 & фенол & 1,8 & 23 & $\begin{array}{l}\text { 3-изобутилгексагидропирроло } \\
\text { (1,2-a) пиразин-1,4-дион }\end{array}$ & 2,1 \\
\hline 3 & $\begin{array}{l}\text { этиловый эфир 4-оксипентановой } \\
\text { (левулиновой) кислоты }\end{array}$ & 0,4 & 24 & $\begin{array}{l}\text { этил (2Е)-3-(4-гидрокси-3- } \\
\text { метоксифенил) -2-пропенонат }\end{array}$ & 1,1 \\
\hline 4 & 2-метокси фенол (гваякол) & 1,0 & 25 & $\begin{array}{l}\text { этиловый эфир гексадекановой } \\
\text { (пальмитиновой) кислоты }\end{array}$ & 2,8 \\
\hline 5 & 4-этил фенол & 2,1 & 26 & $\begin{array}{l}\text { этиловый эфир октадекановой } \\
\text { (стеариновой) кислоты }\end{array}$ & 0,9 \\
\hline 6 & $\begin{array}{l}\text { диэтиловый эфир бутандиовой } \\
\text { (янтарной) кислоты }\end{array}$ & 0,3 & 27 & $\begin{array}{l}\text { этиловый эфир нонадекановой } \\
\text { кислоты }\end{array}$ & 1,4 \\
\hline 7 & $\begin{array}{l}\text { 4-этил, 2-метокси фенол (4 - этил } \\
\text { гваякол) }\end{array}$ & 1,5 & 28 & $\begin{array}{l}\text { этиловый эфир эйкозановой } \\
\text { (арахиновой) кислоты }\end{array}$ & 2,7 \\
\hline 8 & 2,6-диметокси фенол (сирингол) & 1,2 & 29 & 1-нонадецен & 0,9 \\
\hline 9 & $\begin{array}{l}\text { 4-пропил, 2-метокси фенол (4 } \\
\text {-пропил гваякол) }\end{array}$ & 1,2 & 30 & $\begin{array}{l}\text { этиловый эфир докозановой } \\
\text { (бегеновой) кислоты }\end{array}$ & 2,8 \\
\hline 10 & $\begin{array}{l}\text { 2-метил-1Н-изоиндол-1,3(2Н)-дион } \\
\text { (N- метилфталимид) }\end{array}$ & 1,3 & 31 & 5-метил, 6-генейкозен-11-он & 0,9 \\
\hline 11 & 5-гидроксиметил, 2-пирродилинон & 3,9 & 32 & $\begin{array}{l}\text { этиловый эфир трикозановой } \\
\text { кислоты }\end{array}$ & 2,1 \\
\hline 12 & $\begin{array}{l}\text { 4-(1-пропенил), 2-метокси фенол } \\
\text { (4 - пропенилгваякол) }\end{array}$ & 1,1 & 33 & 3,5-диметил, 6-генейкозен-11-он & 0,8 \\
\hline 13 & $\begin{array}{l}\text { 2-этил-1Н-изоиндол-1,3(2Н)-дион } \\
\text { (N- этилфталимид) }\end{array}$ & 0,7 & 34 & $\begin{array}{l}\text { этиловый эфир тетракозановой } \\
\text { (лигноцериновой) кислоты }\end{array}$ & 10,8 \\
\hline 14 & 4-гидрокси-3-метокси ацетофенон & 1,8 & 35 & 1 - докозен & 2,3 \\
\hline 15 & $\begin{array}{l}\text { этиловый эфир } \\
\text { 4-гидроксибензойной кислоты } \\
\text { (этилпарабен) }\end{array}$ & 1,1 & 36 & $\begin{array}{l}\text { этиловый эфир 3,6 диметил } \\
\text { докозановой (бегеновой) кислоты }\end{array}$ & 0,3 \\
\hline 16 & $\begin{array}{l}\text { 1-(4-гидрокси-3 метокси) - 2- } \\
\text { пропанон (гваяцилацетон) }\end{array}$ & 0,8 & 37 & гексадекан тиол & 2,3 \\
\hline 17 & $\begin{array}{l}\text { 3,4-диэтил, диметиловый эфир 2,4- } \\
\text { гександиеновой кислоты }\end{array}$ & 1,5 & 38 & $\begin{array}{l}\text { этиловый эфир октакозановой } \\
\text { (монтановой) кислоты }\end{array}$ & 14,5 \\
\hline 18 & $\begin{array}{l}\text { метиловый эфир } \\
4 \text {-гидроксибензолпропановой } \\
\text { кислоты }\end{array}$ & 1,0 & 39 & $\begin{array}{l}\text { этиловый эфир } \\
\text { 3-метилтетракозановой } \\
\text { (лигноцериновой) кислоты }\end{array}$ & 7,6 \\
\hline 19 & $\begin{array}{l}\text { 4-(2-пропенил), 2,6-диметокси } \\
\text { фенол (4-(2-пропенил) - гваякол) }\end{array}$ & 0,9 & 40 & $\begin{array}{l}\text { этиловый эфир нонакозановой } \\
\text { кислоты }\end{array}$ & 9,1 \\
\hline 20 & $\begin{array}{l}\text { этил-(4-гидрокси-3-метоксифенил) } \\
\text { пропионат }\end{array}$ & 0,3 & 41 & $\begin{array}{l}\text { этиловый эфир } 5 \text { - метил } \\
\text { октакозановой (монтановой) } \\
\text { кислоты }\end{array}$ & 3,0 \\
\hline 21 & не идентифицирован & 2,6 & 42 & $\begin{array}{l}\text { этиловый эфир 4, } 6 \text { - диметил } \\
\text { гексакозановой (церотиновой) } \\
\text { кислоты }\end{array}$ & 2,7 \\
\hline
\end{tabular}

\footnotetext{
* \% от суммы площадей всех пиков
} 
Таблица 2. Вещественный состав продуктов, полученных экстракцией сапропеля органоминерального типа С-2 в этаноле при $200{ }^{\circ} \mathrm{C}$

\begin{tabular}{|c|c|c|c|c|c|}
\hline № & Соединение & $\% *$ & № & Соединение & $\% *$ \\
\hline 1 & $\begin{array}{l}\text { этиловый эфир } 2 \text { - гидрокси- } \\
\text { пропановой (молочной кислоты) } \\
\text { кислоты }\end{array}$ & 8,3 & 26 & $\begin{array}{l}\text { 1-ацетальдегид -2,6,6-триметил - } \\
\text { 1-циклогексен }\end{array}$ & 2,2 \\
\hline 2 & метил пиразин & 2,3 & 27 & $\begin{array}{l}\text { метил 6-деокси-2-О- } \\
\text { метилгексапиранозид }\end{array}$ & 3,0 \\
\hline 3 & $\begin{array}{l}\text { этиловый эфир карбаминовой } \\
\text { кислоты (уретан) }\end{array}$ & 3,9 & 28 & Ванилин лактозид & 1,7 \\
\hline 4 & этил пиразин & 0,8 & 29 & 2-метокси-4-(1-пропенил)-фенол & 4,1 \\
\hline 5 & 5-метил фурфурол & 1,7 & 30 & $\begin{array}{l}\text { 2,4- диметокси, 2,3 - } \\
\text { диметилбензол }\end{array}$ & 0,7 \\
\hline 6 & $\begin{array}{l}\text { фениловый эфир этановой } \\
\text { (уксусной) кислоты }\end{array}$ & 1,9 & 31 & $\begin{array}{l}\text { этиловый эфир додекановой } \\
\text { (лауриновой) кислоты }\end{array}$ & 0,5 \\
\hline 7 & пиррол - 2-карбоксиальдегид & 1,8 & 32 & этиловый эфир деценовой кислоты & 1,7 \\
\hline 8 & $\begin{array}{l}\text { пиррол - 2-карбоксиальдегид, } \\
\text { 5-метил }\end{array}$ & 0,6 & 33 & $\begin{array}{l}\text { 2-метилпропиловый эфир } \\
\text { 3-метоксибензойной кислоты }\end{array}$ & 0,8 \\
\hline 9 & 2-тиофенэтанамин & 1,1 & 36 & $\begin{array}{l}\text { 4-(2-пропенил) - 2,6- } \\
\text { диметоксифенол (4-(2-пропенил) - } \\
\text { гваякол) }\end{array}$ & 1,0 \\
\hline 10 & $\begin{array}{l}\text { этиловый эфир 4-оксипентановой } \\
\text { (левулиновой) кислоты }\end{array}$ & 2,0 & 35 & $\begin{array}{l}\text { этиловый эфир додеценовой } \\
\text { кислоты }\end{array}$ & 1,0 \\
\hline 11 & 1-ацетил -2- метилциклопентен & 2,2 & 36 & $\begin{array}{l}\text { этиловый эфир тридекановой } \\
\text { кислоты }\end{array}$ & 1,8 \\
\hline 12 & $\begin{array}{l}\text { бутиловый эфир пентановой } \\
\text { (валериановой) кислоты }\end{array}$ & 0,8 & 37 & $\begin{array}{l}\text { этиловый эфир 3-гидрокси } \\
\text { додекановой (лауриновой) кислоты }\end{array}$ & 1,9 \\
\hline 13 & 3,5-диметил-1,2,4-тритиолан & 3,1 & 38 & 6,10,14-триметил-2-пентадеканон & 3,1 \\
\hline 14 & 1,2,3,4-тетрагидронафталин & 3,9 & 39 & $\begin{array}{l}\text { этиловый эфир тетрадекановой } \\
\text { (миристиновой) кислоты }\end{array}$ & 0,6 \\
\hline 15 & 2-этилфенол & 1,2 & 40 & $\begin{array}{l}\text { этиловый эфир пентадекановой } \\
\text { кислоты }\end{array}$ & 1,0 \\
\hline 16 & циклопентациклогептен (Азулен) & 4,5 & 41 & не идентифицирован & 1,7 \\
\hline 17 & 1-(2,4-диметил-3-фурил)этанон & 2,3 & 42 & 2-гексадеканол & 0,9 \\
\hline 18 & не идентифицирован & 1,1 & 43 & $\begin{array}{l}\text { этиловый эфир пентадеценовой } \\
\text { кислоты }\end{array}$ & 1,2 \\
\hline 19 & 2,3-дигидробензофуран & 2,7 & 44 & Метил-4-1-метил маннозид & 1,0 \\
\hline 20 & не идентифицирован & 0,6 & 45 & $\begin{array}{l}\text { этиловый эфир гексадекановой } \\
\text { (пальмитиновой) кислоты }\end{array}$ & 8,2 \\
\hline 21 & $\begin{array}{l}\text { этиловый эфир 7-гидрокси-окт-3- } \\
\text { еновой кислоты }\end{array}$ & 0,7 & 46 & $\begin{array}{l}\text { диэтиловый эфир нонандиовой } \\
\text { кислоты }\end{array}$ & 0,5 \\
\hline 22 & $\begin{array}{l}\text { 1-(3,4-дигидрокси фенил)-2- } \\
\text { (метиламино)-этанон (Адреналон) }\end{array}$ & 1,6 & 47 & $\begin{array}{l}\text { метиловый эфир 4-оксинонадец-10- } \\
\text { еновой кислоты }\end{array}$ & 0,5 \\
\hline 23 & не идентифицирован & 2,1 & 48 & $\begin{array}{l}\text { этиловый эфир гептадекановой } \\
\text { (маргариновой) кислоты }\end{array}$ & 1,9 \\
\hline 24 & $\begin{array}{l}\text { этиловый эфир 2-ноненовой } \\
\text { кислоты }\end{array}$ & 3,7 & 49 & $\begin{array}{l}\text { этиловый эфир октадекановой } \\
\text { (стеариновой) кислоты }\end{array}$ & 1,4 \\
\hline 25 & 2,4-диметоксифенол (сирингол) & 2,6 & & & \\
\hline
\end{tabular}

* \% от суммы площадей всех пиков. 
мицеллюлозы растительной биомассы. Высокое содержание в сапропеле C-1 жирных кислот с количеством атомов углерода в молекуле до 29 позволяет предположить, что их источником могли быть липиды и воски, входящие в состав исходных биоматериалов, которые участвовали в процессе образования сапропелей.

\section{Выводы}

1. Установлено, что в процессе экстракции сапропелей Новосибирской области органического (оз. Качкульня) и органоминерального (оз. Барчин) типов при 50 и $76{ }^{\circ} \mathrm{C}$ тип сапропеля оказывал слабое влияние на выход продуктов, который составил соответственно 1,8 и 2,6 мас.\% в расчете на абсолютно сухое органическое вещество сапропеля. Показано, что повышение температуры экстракции до $200{ }^{\circ} \mathrm{C}$ при давлении, обеспечивающем нахождение экстрагента в жидкой фазе, приводит к резкому увеличению выхода экстрагируемых продуктов до 36,1 и 24,6 мас.\% для сапропелей органического и органоминерального типов.

2. Показано, что тип исследуемых сапропелей существенно влияет на состав экстрактов. Продукты из сапропеля органического типа содержат 68,1 \% этиловых эфиров, преимущественно жирных кислот с числом атомов углерода в молекуле от 18 до 29. В экстрактах сапропелей органоминерального типа относительное содержание этиловых эфиров равно 43,6 \%, в состав которых кроме этиловых эфиров жирных кислот входят этиловые эфиры окси- и гидроксикислот, наиболее высокое содержание обнаружено для этилового эфира 2-гидроксипропановой (молочной) кислоты - 8,3 \% и этилового эфира 4-оксипентановой (левулиновой) кислоты $-2,0 \%$, что, соответственно, в 13,8 и 5,0 раз больше, чем в продуктах из сапропеля С-1.

3. Отличительной особенностью экстрактов сапропеля органоминерального типа является наличие в его составе углеводов, наибольшее содержание среди которых установлено для метил-6-деокси-2-О-метилгексапиранозида - $3 \%$, и соединений, включающих в свой состав фурановый цикл, таких как 5-метил фурфурол - 1,7 \% .

\section{Список литературы}

1. Косов В.И. Сапропель. Ресурсы, технологии, геоэкология. СПб.: Наука. 2007. 224 с. [Kosov V.I. Sapropel. Resources, technology, geo-ecology. SPb .: Science. 2007. 224 p.].

2. Курзо Б.В., Богданов С.В. Генезис и ресурсы сапропелей Белоруссии. Минск: Наука и техника, 1989. 176 c. [Kurzo B.V., Bogdanov S.V. Genesis and sapropel resources of Belarus. Mn.: Science and Technology. 1989. 176 p.].

3. Дычко К.А., Тюнина М.А., Рыжова Г.Л. Влияние вибромагнитного воздействия на выход и состав гидрофильных и липофильных биологически активных веществ из сапропеля // Химия растительного сырья. 2012. №2. C.155-163. [Dychko K.A., Tyunina M.A., Ryzhova G.L. Effect of vibromagnetic influence on the yield and composition of the hydrophilic and lipophilic bioactive substances from sapropel. Khimija Rastitel'nogo Syr'ja. 2012. N.2. C.155-163].

4. Krivonos O.I., Plaksin G.V. Extraction of Biologically Active Substances from Sapropels with Liquid and Supercritical Carbon Dioxide // Russian Journal of Physical Chemistry B. 2010. V.4. N.8, P.1171-1177.

5. Рыжова Г.Л., Тюнина М.А., Дычко К.А.. Определение жирных кислот в продуктах вибромагнитной переработки сапропеля методом хромато-масс-спектрометрии // Жур- 
нал аналитической химии. 2013. T. 68. № 8. C. 808-814 [Ryzhova G.L., Yudin M.A., Dychko K.A. Determination of fatty acids in products of the vibromagnetic treatment of sapropel by chromatography-mass-spectrometry GC-MS // Journal of Analytical Chemistry. 2013. V. 68. N. 8. P. 808-814].

6. Платонов В.В., Хадарцев А.А., Фридзон К.Я., Чуносов С.Н. Химический состав и биологическая активность сапропеля оз. Глубокое (Татарстан) // Вестник новых медицинских технологий. 2014. Т. 21. № 3. C.199-204 [Platonov V.V., Khadartsev A.A., Fridzon K.Y., Chunosov S.N. Chemical composition and biological activity of sapropel lake. Deep (Tatarstan) // Bulletin of new medical technologies. 2014. V. 21. N 3. P.199-204].

7. Ломовский О.И., Болдырев В.В. Механохимия в решении экологических задач. Новосибирск: РАН, 2006. 228 с. [Lomovskii O.I., Boldyrev V.V. Mechanochemistry in solving of environmental problems. Novosibirsk, Russian Academy of Sciences. 2006. 228 p.]

8. Sanchez-Camargo A.P., Martinez-Correa H.A. et al. Supercritical $\mathrm{CO}_{2}$ extraction of lipids and astaxanthin from Brazilian redspotted shrimp waste (Farfantepenaeus paulensis) // The Journal of Supercritical Fluids. 2011. V. 56. P. 164-173.

9. Speelman E.N., Reichart G.-J., de Leeuw J.W., Rijpstra W.I.C., Sinninghe Damsté J.S. Biomarker lipids of the freshwater fern Azolla and its fossil counterpart from the Eocene Arctic Ocean // Organic Geochemistry. 2009. V. 40. P. 628-637.

10. Шарыпов В.И., Береговцова Н.Г., Барышников С.В., Таран О.П., Страховенко В.Д., Кузнецов Б.Н. Изучение процесса термического растворения в этаноле сапропелей озер Качкульня и Барчин Новосибирской области // Химия растительного сырья. 2013. №4. C.213-218. [Sharypov V.I., Beregovtsova N.G., Baryshnikov S.V., Taran O.P., Strakhovenko V.D., Kuznetsov B.N. Study of thermal dissolution in ethanol of sapropels from Kachkulnya and Barchin lakes of Novosibirsk region // Khimija Rastitel'nogo Syr'ja. 2013. N.4. P.213218.]

11. Fisk A.T., Stern G.A., Hobson K.A., Strachan W.J., Loewen M.D., Norstrom R.J.Persistent organic pollutants (POPs) in a small, herbivorous, arctic marine zooplankton (Calanus hyperboreus): Trends from April to July and the influence of lipids and trophic transfer // Mar Pollut. Bull. 2001. V.43. P.93-101.

12. Balmer M.E., Buser H.R., Müller M.D., Poiger T. Occurrence of some organic UV filters in wastewater, in surface waters, and in fish from Swiss lakes // Environ Science Technol. 2005. V.39. P.935-962.

13. Zhang Z., Metzger P., Zhang J.P.S. Co-occurrence of long chain diols, keto-ols, hydroxy acids and ketoacids in recent sediments of Lake El Junco, Galápagos Islands Organic Geochemistry. 2011. V.42. P. 823-837.

14. Buckmann A.H., Wong C.S., Chow E.A., Brown S.B., Solomon K.R., Fisk A.T. Biotransformation of polychlorinated biphenyls (PCBs) and bioformation of hydroxylated PCBs in fish // Aquatic Toxicol. 2006. V.78. N.2. P.176-85.

15. Law K., Palace V.P., Halldorson T., Danell R., Wautier K., Evans B., Alaee M., Marvin C., Tomy G.T. Dietrary accumulation of hexabromocyclododecane diastereoisomers in juvenile rainbow trout (Oncorhynchus mykiss) I: Bioaccumulation parameters and evidence of bioisomerization // Environ. Toxicol. Chem. 2006. V. 25. N.7. P.1757-1761. 
16. Chu S., Metcalf C.D. Analysis of paroxetine, fluoxetine and norfluoxetine in fish tissues using pressurized liquid extraction, mixed mode solid phase extraction cleanup and liquid chromatographytandem mass spectrometry // J. Chromatogr. A. 2007. V.1163. N.1-2. P.112-118.

17. Houde M., Muir D.C.G., Kidd K.A., Guildford S., Drouillard K., Evans M.S., Wang X., Whittle D.M., Haffner D., Kling H. Influence of lake characteristics on the biomagnification of persistent organic pollutants in lake trout food webs // Environ. Toxicol. Chem. 2008. V. 27. N.10. P.2169-2178.

18. Holser R.A., Akin D.E. Extraction of lipids from flax processing waste using hot ethanol // Industrial crops and products. 2008. V. 27. P. 236-240

19. Strakhovenko V.D., Taran O.P., Ermolaeva N.I. Geochemical characteristics of the sapropel sediments of small lakes in the Ob' - Irtysh interfluves // Russian Geology and Geophysics. 2014. V.55. P.1160-1169. 